\title{
BARROS, R. (2011). Genealogia dos conceitos em Educação de Adultos: Da Educação Permanente à Aprendizagem ao Longo da Vida - Um estudo sobre os fundamentos político-pedagógicos da prática educacional. Lisboa: Chiado Editora
}

O livro de Rosanna Barros aqui recenseado é provido de um forte, e nunca oculto, posicionamento político relativamente à prática educacional, em geral, e à prática educacional de adultos, em particular, entendida esta em todas as suas dimensões. A Autora recusa a possibilidade de existência de um olhar despolitizado sobre os conceitos críticos e pedagógicos do campo da educação de adultos, alertando, de forma muito sustentada, para o processo de "ressemantização política" (p. 20) que, nas últimas décadas, tem atingido o quadro crítico e conceptual deste campo, assumindo-se como defensora de uma educação de adultos em contracorrente, em que as prioridades sejam a apologia da democracia solidária e a transformação social em benefício de cada ser humano e da sociedade, em geral.

A obra organiza-se em duas partes: na I Parte, são abordadas analiticamente questões de heurística na Educação de Adultos, estabelecendo-se um mapa (inter)nacional dos conceitos e fundamentos educacionais gerais. Nessa análise, são definidos os conceitos de educação, formação, aprendizagem, ensino e desenvolvimento como sendo nucleares na área global da educação e estabelece-se entre eles ordens de relação preferenciais que foram conceptualmente contextualizadas a bem da clarificação do conceito de educação de adultos, até porque "os conceitos servem ... a comunicação" (p. 21). No que se refere à educação de adultos, em particular, os conceitos centrais são os de adulto/adultez, experiencial, formal, não formal e informal.

O argumento, nesta I Parte, reclama a "metamorfose discursiva", a "flutuação terminológica" e a "insuficiente teorização" (p. 40) como os principais fatores responsáveis pela manipulação discursiva a que, defendese, a identidade da educação de adultos tem sido sujeita.

Na II Parte, Rosanna Barros aporta a genealogia dos conceitos em Educação de Adultos, percorrendo e problematizando (inter)nacionalmente perspetivas político-filosóficas estruturantes do setor. Assim, nesta obra problematiza-se aqueles que se consideram ser os binómios conceptuais fundamentais na educação de adultos, nomeadamente, educação 
permanente, sociedade da aprendizagem, organização qualificante e aprendizagem ao longo da vida, lançando a dúvida de que a educação cumpra atualmente a sua dupla missão de, por um lado, potenciar o enraizamento de cada indivíduo à ordem social que o precede e, por outro, impulsionar a transformação do indivíduo e da sociedade.

Nesta genealogia dos conceitos relembra-se que, apesar de a Educação de Adultos, entendida na sua tridimensionalidade, ser inerente à vida do ser humano e, por isso, a todos os tempos e a todos os espaços, a definição de um conceito de 'educação de adultos' é historicamente recente, estando vinculado à formação e ao desenvolvimento dos sistemas de educação escolar ocidental modernos, sobretudo a partir da revolução francesa, em que os Estados abraçam a missão de alfabetizar e formar profissionalmente as pessoas. No entanto, são as agências organizadas da ONU, principalmente a UNESCO, que, depois da II Guerra Mundial, sistematizam o conceito e criam as condições para que este se constitua como um campo específico da educação, o qual virá a ser fortemente afetado por "perspectivas teóricas e disciplinares sobre as metodologias das práticas da educação de adultos" (p. 96) e por "perspectivas políticas e filosóficas sobre as ideologias dos discursos da educação de adultos” (p. 96).

Assim, na obra reflete-se sobre as práticas e os discursos em educação de adultos a partir das dimensões émica e ética, indagando sobre a relação entre o saber e o poder neste campo, ao longo dos tempos. Centrando a sua análise nos binómios conceptuais de 'educação permanente' e de 'aprendizagem ao longo da vida', Rosanna Barros apresenta-os como paradigmas educativos radicalmente opostos ao nível das suas géneses históricas e políticas, ao nível do papel, da missão e da intencionalidade que lhes são atribuídos, mas também ao nível da visão do mundo que existe e do mundo que se quer que exista.

São aqui demarcadas claramente duas épocas, caracterizadas por visões político-filosóficas diferentes: uma primeira, na última metade do século $X X$, a época dourada, e que é caracterizada pela expansão mundial de práticas de educação de adultos, de acordo com a perspetiva da educação permanente, e acompanhada por elevados índices de crescimento económico nos países ricos. A outra época, à qual a autora chama negra, rapidamente substitui a de ouro, e é caracterizada pela perspetiva da aprendizagem ao longo da vida. É de salientar que as duas perspetivas atribuem papéis e 
missões manifestamente contraditórias à educação de adultos: se a primeira desabrocha enquanto tentativa de defesa do bem comum através da edificação de uma sociedade de aprendizagem (p. 182), a segunda afirma-se, quase de forma hegemónica do ponto de vista teórico e conceptual, no início do século XXI, como estratégia de defesa dos interesses privados através da estruturação de uma sociedade cognitiva (p. 182).

Esta obra fornece fundamentos aprofundados que acautelam o leitor para o facto de a opção política por um ou por outro paradigma educativo ter implicações bem distintas, mas igualmente sérias, na vida dos indivíduos e da sociedade: enquanto a educação permanente é legatária de uma tradição de manancial crítico fundado nas correntes de pensamento marxista e neomarxista, e se eleva a partir dos ideais democráticos e da defesa dos direitos humanos, a aprendizagem ao longo da vida é descendente de uma tradição tecnocrática e gestionária alicerçada na escola de pensamento funcionalista. Enquanto o paradigma da educação permanente fornece pistas para que o ser humano se construa como cidadão e sujeito ator do seu processo existencial, o paradigma da aprendizagem ao longo da vida parece apenas pretender convertê-lo em objeto que sirva o aumento da eficácia da atividade produtiva, a gestão da força de trabalho, a prevenção da conflitualidade social e a promoção da adaptabilidade da pessoa através do desenvolvimento de competências técnicas. Da leitura deste livro resulta uma melhor consciência no leitor do carácter político dos conceitos que usamos em educação e dos riscos associados à passagem do político ao técnico num sector como o da educação de adultos (cf. p. 156-186).

Em síntese, a autora do estudo que enforma esta obra manifesta o desejo de que a verdadeira utopia se cumpra: não é uma utopia sinónima de intangibilidade, mas aquela que encontra o seu significado no anseio de alcançar uma sociedade democrática e igualitária, na qual ninguém fique impossibilitado de realizar o seu potencial humano. Nesta busca pela utopia, os construtores teórico-pedagógicos críticos são imprescindíveis.

Ora, aceitando o repto de posicionamento político-educacional que a autora lança aos educadores(as), gostaríamos, como autora desta recensão e como educadora social, de sublinhar que, no nosso entender, atualmente, e devido a toda a conjuntura política, social e económica, não podemos aceitar a educação de adultos tecnicista que nos é proposta pelas organizações ocidentais, pois também elas definiram os seus programas com base nas 
imposições dos mercados de investimento, também elas se contentam com uma sociedade em que os insolventes e os pobres não sejam demasiados (de acordo com os seus critérios), mas sejam os necessários para manter o sistema a funcionar. E, assim, corremos o risco de prepararmos as pessoas para o mercado de trabalho, mas não as prepararmos para a vida; ensinarmos as pessoas a ler, a escrever, a dominar as tecnologias e a competir, mas não as ensinarmos a serem solidárias, colaborativas, éticas e sensíveis à pessoa do outro, o que terá consequências nefastas na construção de uma sociedade que, cada vez mais, é menos igualitária, pacífica e feliz (Freire, 1990).

$\mathrm{Na}$ Conclusão deste livro, Rosanna Barros afirma, com mestria e sensibilidade, que "a luta contra o neoliberalismo terá de ser feita (...) também pela via do simbólico, ou seja, pela reconstrução do pensamento políticopedagógico em moldes teórico-conceptuais que contribuam colectivamente ... para desnaturalizar as novas/velhas formas de opressão e desmistificar a consciência da realidade" (p. 192). Neste sentido, esta publicação é incontestavelmente um contributo importante para todos os que se preocupam com o presente e o futuro da educação de adultos: não só apresenta uma discussão profunda, e sustentada em investigação científica, sobre a influência da globalização neoliberal nas conceções educativas veiculadas por diversas organizações internacionais de naturezas distintas, como a ONU ou a OCDE, como também questiona as consequências a nível humano (individual e social) que daí advêm, lançando um desafio fundamental às comunidades de práticas para que retomem os conceitos críticos do campo como léxico de resistência local à instrumentalização da educação de adultos perpetuada hoje nos contextos hegemónicos da decisão política acerca da aprendizagem ao longo da vida dos adultos.

\section{Nota}

1 Freire, P. (1990). La Naturaleza Política de la Educación - Cultura, Poder y Liberación. Barcelona: Ediciones Paidós.

Dora Cristina Valério de Jesus Luís Centro Comunitário de Estoi 